\title{
Pengaruh Ukuran Partikel Bentonit Alam Teraktivasi Pada Penurunan Limbah Cair Sarung Tenun Samarinda
}

\author{
Mustafa $^{1 *}$, Marinda Rahim ${ }^{2}$, Muh. Irwan $^{3}$, Desi Purnama Sari ${ }^{4}$ \\ ${ }^{1234}$ Jurusan Teknik Kimia, Politeknik Negeri Samarinda, Kalimantan Timur, 75131, Indonesia
}

\begin{tabular}{|c|c|}
\hline Article Info & ABSTRAK \\
\hline $\begin{array}{l}\text { Article history: } \\
\text { Received : } \\
\text { Pebruary } 19^{\text {th }}, 2020 \\
\text { Revised: } \\
\text { Apr } 30^{\text {th }}, 2020 \\
\text { Accepted } \\
\text { May } 25^{\text {th }}, 2020\end{array}$ & $\begin{array}{l}\text { Salah satu industri yang perlu mendapat perhatian adalah usaha industri sarung tenun Samarinda. } \\
\text { Industri ini menghasilkan limbah cair yang dihasilkan dari proses pewarnaan dengan menggunakan } \\
\text { pewarna De Congo Red yang merupakan pewarna organik. Umumnya usaha Industri sarung tenun } \\
\text { Samarinda ini membuang limbahnya langsung ke sungai Mahakam di sekitar rumah atau lokasi } \\
\text { penenunan yang akan menimbulkan dampak merugikan bagi lingkungan. Proses utama dalam } \\
\text { penelitian ini adalah adsorpsi dengan bentonit aktif bertujuan untuk mengetahui pengaruh ukuran } \\
\text { partikel bentonit yang telah di aktivasi dalam proses adsorbsi. Unjuk kerja proses adsorpsi diukur } \\
\text { melalui parameter BOD, COD, TSS dan, pH dari limbah cair tersebut. Proses adsorbsi dilakukan } \\
\text { dengan mencampurkan bentonit aktif dan limbah cair sarung tenun Samarinda dengan } \\
\text { perbandingan } 0,25 \text { gram : } 1 \mathrm{~mL} \text {. Campuran tersebut kemudian diaduk selama } 1 \text { jam dengan } \\
\text { kecepatan putaran } 468 \mathrm{rpm} \text {. Ukuran bentonit aktif divariasikan sebesar } 210,230,270,310,330 \text {, } \\
370 \text { dan } 400 \text { mesh. Hasil penelitian ini telah menunjukkan bahwa bentonit aktif berukuran } 400 \\
\text { mesh lebih banyak menurunkan nilai BOD, COD, TSS dan pH hingga memenuhi baku mutu sesuai } \\
\text { Keputusan Gubernur Kalimantan Timur Nomor } 26 \text { Tahun } 2002 \text {. Nilai parameter BOD, COD, TSS } \\
\text { dan pH hasil pengolahan tersebut berturut-turut adalah } 34,5 \mathrm{mg} / \mathrm{L}, 64 \mathrm{mg} / \mathrm{L}, 168 \mathrm{mg} / \mathrm{L} \text { dan pH } 8 \text {. }\end{array}$ \\
\hline
\end{tabular}

Kata kunci: Adsorpsi, bentonit aktif , BOD, COD, pH, TSS.

\begin{abstract}
ABSTRAK
One industry that needs attention is Samarinda's woven sarong business. This industry produces liquid waste that is produced from the coloring process using De Congo Red which is an organic dye. Discussing the business of Samarinda's woven sarong industry discharges its waste directly into the Mahakam River around the house or weaving location which will cause a harmful impact on the environment. The main process in this research is adsorption with active bentonite to determine differences in activated bentonite particles in the adsorption process. The performance of the adsorption process through the parameters of BOD, COD, TSS and, pH of the liquid waste. The adsorption process was carried out by mixing active bentonite and Samarinda waste woven gloves with 0.25 grams: $1 \mathrm{~mL}$. The mixture is then stirred for 1 hour at a rotational speed of 468 rpm. The size of the active bentonite was varied by 210, 230, 270, 310, 330, 370 and 400 mesh. The results of this study have proven that active bentonite has 400 mesh more than the BOD, COD, TSS and $\mathrm{pH}$ values according to the standard requirements according to the Decree of the Governor of East Kalimantan No. 26/2002. Also involved were $34.5 \mathrm{mg} / \mathrm{L}, 64 \mathrm{mg} / \mathrm{L}, 168 \mathrm{mg} / \mathrm{L}$ and $\mathrm{pH} 8$.
\end{abstract}

Keywords: Adsorption, active bentonite, $B O D, C O D, p H$, TSS.

Corresponding Author:

Mustafa,

Department of Chemical Engineering

Politeknik Negeri Samarinda,

Jl, Ciptomangunkusumo Kampus Gunung Lipan, Samarinda 75131, Indonesia

Email: musmustafa76@yahoo.com 


\section{PENDAHULUAN}

Pesatnya aktifitas perindustrian dewasa ini, selain bertujuan untuk memenuhi kebutuhan dan kesejahteraan manusia, juga menghasilkan dampak negatif bagi mahluk hidup maupun bagi lingkungan, dimana setiap kegiatan industri menghasilkan limbah dari hasil prosesnya.

Salah satu ind u st i yang perlu mendapat perhatian adalah usaha industri sarung tenun Samarinda . Industri ini menghasilkan limbah yang sebagian besar dalam bentuk cair, yang dihasilkan dari proses pewarnaan dengan menggunakan pewarna De Congo Red yang merupakan pewarna organik. Umumnya usaha Industri sarung tenun Samarinda ini membuang limbahnya langsung ke sungai Mahakam di sekitar rumah atau lokasi penenunan yang akan menimbulkan dampak merugikan bagi lingkungan. Industri sarung tenun Samarinda di Kelurahan Baqa mencapai 50 industri rumah tangga yang ada sejak dahulu secara turun-menurun. Berdasarkan survei yang dilakukan di lapangan, setiap industri membuang limbah cair warnanya sejumlah $\pm 100 \mathrm{~L} / 3$ hari atau pembuangan dalam pertahun mencapai 608.333,3 L [10]. Air lingkungan yang telah tercemar memiliki kandungan oksigen yang sangat rendah. Hal itu dikarenakan oksigen yang terlarut di dalam air diserap oleh mikroorganisme untuk memecah/mendegradasi bahan buangan organik menjadi bahan yang mudah menguap. Selain dari itu, bahan buangan organik juga dapat bereaksi dengan oksigen yang terlarut di dalam air mengikuti reaksi oksidasi biasa. Makin banyak bahan buangan organik yang ada di dalam air, maka makin sedikit sisa kandungan oksigen yang terlarut di dalamnya sehingga mengganggu ekosistem dalam air.

Untuk menghindari pencemaran terhadap lingkungan khususnya biota sepanjang sungai Mahakam maka sebelum dibuang ke lingkungan limbah cair industri sarung tenun Samarinda perlu diolah terlebih dahulu yaitu dengan menurunkan konsentrasi limbah zat warna organik. Salah satu cara mengurangi konsentrasi zat organik dengan metode adsorpsi menggunakan adsorben bentonit.

Beberapa peneliti menggunakan karbon aktif untuk mengadsorpsi material organik terlarut. Tetapi karena tingginya harga adsorben karbon aktif serta sulitnya diregenerasi, mendorong para peneliti untuk mencari material lain sebagai penggantinya. Salah satu bahan yang menarik untuk digunakan sebagai adsorben adalah material anorganik alam, misalnya lempung [4].

Penggunaan lempung sebagai adsorben mempunyai beberapa keunggulan karena lempung khususnya jenis bentonit mempunyai struktur antar lapis yang dapat dimodifikasi sehingga dapat memperbaiki daya adsorpsinya. Disamping itu pemanfaatan lempung sebagai adsorben dapat diregenerasi [8].

Indonesia mempunyai cadangan bentonit cukup besar, endapan bentonit Indonesia tersebar di P. Jawa, P. Sumatera, sebagian P. Kalimantan dan P. Sulawesi, dengan cadangan diperkirakan lebih dari 380 juta ton (http://mineral-imfo.blogspot.com/2009 03 01). Pada penelitian kali ini akan dicoba melakukan penjerapan zat warna organik dari limbah cair sarung tenun Samarinda dengan menggunakan bentonit sebagai adsorben. Indrawati dan Widodo (2005) telah melakukan penelitian adsorpsi zat warna rhodamin B dengan menggunakan bentonit yang diaktivasi dengan menggunakan $\mathrm{HCl}$ maupun $\mathrm{H}_{2} \mathrm{SO}_{4}$. Sedangkan pada penelitian ini bentonit yang telah diaktivasi akan digunakan untuk mengadsorpsi zat warna jenis De Congo Red yang merupakan bahan dasar zat warna pada industri sarung tenun Samarinda.

Pada aplikasi dalam proses adsorpsi keberhasilannya dipengaruhi oleh beberapa faktor yaitu pengadukan, ukuran butir, kelarutan adsorbat, ukuran molekul adsorbat, derajat keasaman, temperatur, waktu jerap dan konsentrasi. Dalam penelitian ini adalah pengaruh ukuran partikel bentonit yang telah di aktivasi dalam proses adsorbsi limbah cair industri sarung tenun Samarinda terhadap parameter BOD, COD, TSS dan $\mathrm{pH}$ limbah cair tersebut.

\section{METODOLOGI}

a). Alat Dan Bahan Yang Digunakan :

$>$ Alat yang digunakan dalam penelitian antara lain : screen (ayakan), neraca digital, spatula, batang pengaduk, buret $50 \mathrm{~mL}$, labu ukur (100 mL;150 mL;250 mL;1000 mL;dan $2000 \mathrm{~mL})$, pipet Volumetrik $(5 \mathrm{~mL} ; 25 \mathrm{~mL}$;dan $50 \mathrm{~mL})$, gelas ukur $100 \mathrm{~mL}$, magnetic stirrer, gelas kimia $(50 \mathrm{~mL} ; 100 \mathrm{~mL} ; 250 \mathrm{~mL}$; dan $2000 \mathrm{~mL}$ ). corong Buchner, kertas saring whatman no.42, pompa vakum, erlenmeyer vakum 1000 $\mathrm{mL}$, erlenmeyer asah, oven, mortar dan pestle, tray, pipet tetes, hot plate merk Breanstead, kondensor, statip \& klem, desikator, stopwatch, gegep, corong, botol semprot, botol sampel dan tachometer.

$>$ Bahan yang digunakan dalam penelitian antara lain : bentonit alam, aquadest, limbah cair industri sarung tenun Samarinda, $\mathrm{HCl}, \mathrm{K}_{2} \mathrm{Cr}_{2} \mathrm{O}_{7}, \mathrm{Ag}_{2} \mathrm{SO}_{4}$, Phenanthroline Monohydrate, FeSO4.7 $\mathrm{H}_{2} \mathrm{O}, \mathrm{H}_{2} \mathrm{SO}_{4}$ pekat, Indikator universal, Larutan Ferro Aluminium Sulfat, $\mathrm{HgSO}_{4}$ dan Indikator Ferroin 


\section{b). Jalan Penelitian}

\section{$>$ Lokasi Penelitian}

Lokasi penelitian dilakukan di laboratoium riset Teknik Kimia Politeknik Negeri Samarinda dan laboratorium kesehatan Samarinda. Sedangkan tempat pengambilan limbah cair industri sarung tenun berada di jalan Pangeran Bendahara Samarinda Seberang.

$>$ Variabel Variabel Tetap antara lain : Volume limbah, Tekanan atmosfer, Suhu kamar, Kecepatan Pengadukkan

$>$ Variabel Tidak Tetap antara lain : Ukuran partikel 200 mesh; 230 mesh; 270 mesh, 300 mesh, 330 mesh, 370 mesh dan 400 mesh

$>\quad$ Variabel Respon antara lain : COD, BOD, TSS dan $\mathrm{pH}$

\section{Prosedur Penelitian}

- Preparasi Material Pori B

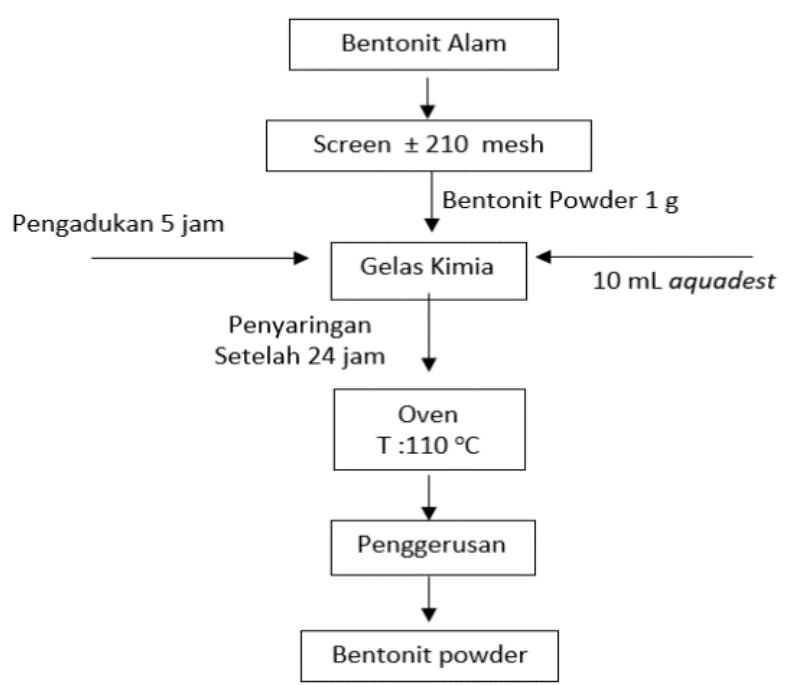

Gambar 1. Diagram Blok Preparasi Material Pori Bentonit

- Aktivasi

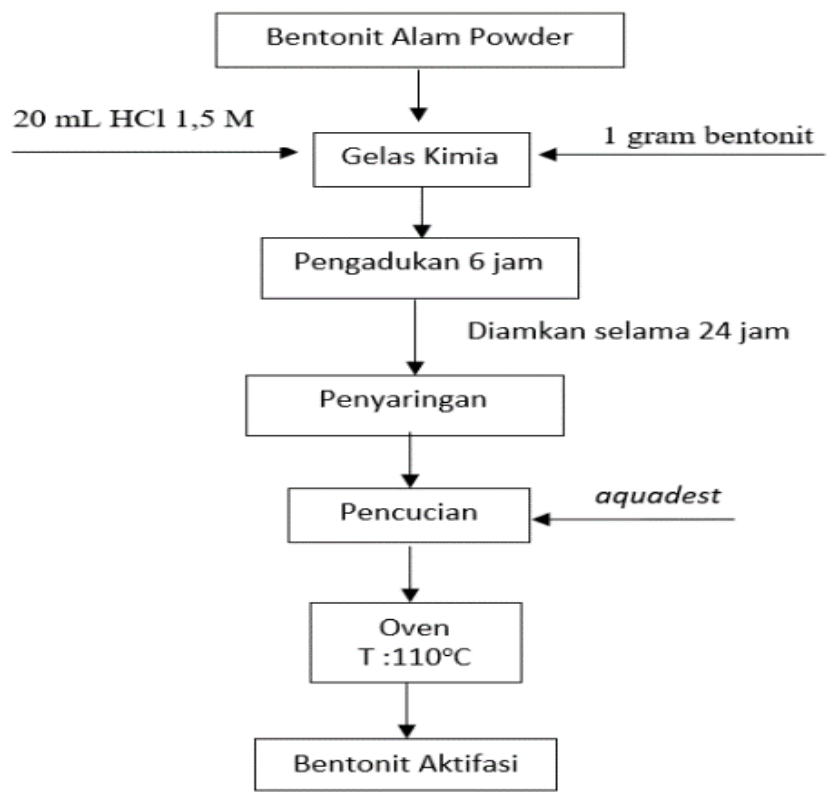

Gambar 2. Diagram Blok Aktivasi Material Pori Bentonit 


\section{Proses Adsorpsi Variasi Ukuran Partikel}

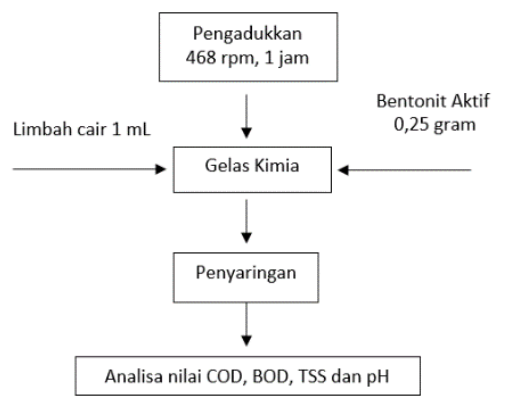

Gambar 3. Diagram Blok Proses Adsorpsi Variasi Ukuran Partikel Material Pori Bentonit

\section{Prosedur Kerja}

\section{Preparasi Material Pori Bentonit}

1. Menimbang 200 gram bentonit alam dan mengayaknya dengan ukuran \pm 200 mesh.

2. Menimbang 130 gram bentonit powder yang telah di ayak dan memasukkannya ke dalam gelas kimia 2 liter.

3. Menambahkan aguadest $1950 \mathrm{~mL}$ kedalam gelas kimia 2 liter dan diaduk dengan stirrer magnetik pada kecepatan pengadukan 468 rpm selama 5 jam kemudian didiamkan hingga 24 jam.

4. Menyaring suspensi bentonit dengan menggunakan kertas saring no. 42 .

5. Mengeringkan endapan bentonit yang telah disaring dalam oven pada suhu $100{ }^{\circ} \mathrm{C}$ hingga bentonit kering kemudian ditimbang.

6. Menggerus bentonit kering dan mengayaknya dengan ukuran \pm 200 mesh (bentonit powder).

\section{Aktivasi}

1. Menimbang 100 gram bentonit yang telah dipreparasi dan menambahkan $2000 \mathrm{~mL} \mathrm{HCl} 1,5 \mathrm{M}$ dengan memasukkannya ke dalam gelas kimia 2 liter.

2. Mengaduk dengan pengaduk magnet selama 6 jam.

3. Mendiamkan selama 24 jam.

4. Menyaring dengan menggunakan kertas saring whatman no. 42, dengan bantuan pompa vakum.

5. Mencuci dengan aquadest hingga $\mathrm{pH}$ nya netral. Pengukuran $\mathrm{pH}$ dilakukan dengan menggunakan indikator universal.

6. Mengeringkan di dalam oven dengan suhu $110{ }^{\circ} \mathrm{C}$ sampai beratnya konstan.

\section{Proses adsorpsi variasi ukuran partikel}

1. Menyiapkan sampel limbah cair sarung tenun Samarinda sebanyak $100 \mathrm{~mL}$ di dalam gelas kimia $200 \mathrm{~mL}$.

2. Menimbang 25 gram bentonit aktif berukuran \pm 210 mesh dan memasukkannya ke dalam sampel limbah.

3. Melakukan proses adsorpsi dengan mengontakkan bentonit dan limbah selama 1 jam disertai dengan pengadukan pada kecepatan $468 \mathrm{rpm}$.

4. Menyaring sampel limbah menggunakan kertas saring no. 42, dengan bantuan pompa vakum.

5. Menganalisa nilai COD, BOD, TSS dan $\mathrm{pH}$ limbah yang telah diolah.

6. Mengulangi prosedur kerja untuk ukuran bentonit aktif \pm 230 mesh sampai dengan \pm 400 mesh.

\section{Analisa COD}

1. Memipet $50 \mathrm{~mL}$ contoh dan memasukkan dalam erlenmeyer $500 \mathrm{~mL}$ ( jika COD > $900 \mathrm{mg} \mathrm{O}$ maka mengulang dengan pemipetan contoh harus lebih kecil dari $50 \mathrm{~mL}$ )

2. Menambahkan $\pm 1 \mathrm{~g} \mathrm{Hg}_{2} \mathrm{SO}_{4}$ dan batu didih, serta menambahkan 5,0 mL reagen asam sulfat secara perlahanlahan.

3. Agar $\mathrm{Hg}_{2} \mathrm{SO}_{4}$ terlarut, maka erlenmeyer sambil digoyang-goyang didinginkan menggunakan aliran air kran, agar senyawa volatil tidak menguap.

4. Menambahkan $25 \mathrm{~mL} \mathrm{~K}_{2} \mathrm{Cr}_{2} \mathrm{O}_{7}$ 0,0147 $\mathrm{M}$ dan mengocok hingga homogen.

5. Memasangkan erlenmeyer pada kondensor sambil mengalirkan air pendingin. 
6. Menambahkan sisa reagen asam sulfat ( $70 \mathrm{~mL}$ ) melalui ujung kondensor yang terbuka, menutup ujung kondensor yang terbuka dengan beaker gelas untuk menghindari kontaminasi benda asing ke dalam larutan dan untuk menghindari lolosnya uap $\mathrm{Hg}$.

7. Memulai refluks selama 2 jam pada suhu $175^{\circ} \mathrm{C}$.

8. Mendinginkan dan membilas bagian dalam kondensor dengan aquadest.

9. Mengencerkan contoh \pm 2 ( dua ) kali dari volume yang ada.

10. Menitrasi kelebihan $\mathrm{K}_{2} \mathrm{Cr}_{2} \mathrm{O}_{7}$ dengan FAS dengan indikator ferroin $2-3$ tetes. Titik akhir ditunjukkan oleh perubahan warna mendadak dari biru kehijauan ke coklat kemerahan.

11. Mengerjakan prosedur yang sama untuk blanko.

12. Melakukan pengerjaan (1) sampai (6) untuk penetapan kontrol standar dengan menggunakan larutan glukosaasam glutamat. Hasil pengukuran yang diperoleh merupakan nilai oksigen terlarut nol hari $\left(\mathrm{C}_{1}\right)$ dan nilai oksigen terlarut 5 hari $\left(\mathrm{C}_{2}\right)$

13. Menghitung nilai COD dengan persamaan

$$
\mathrm{COD}=\frac{(\mathrm{A}-\mathrm{B}) \times \mathrm{MFAS} \times 1000 \times \mathrm{BeO}_{2} \times \mathrm{P}}{\mathrm{V} \text { sampel }}
$$

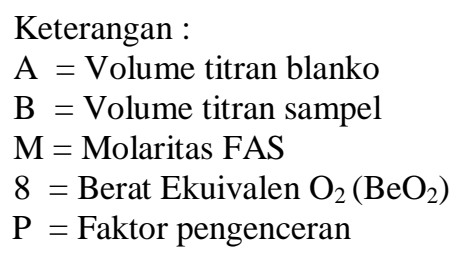

\section{Analisa BOD5}

\section{a. Penyimpanan contoh sesaat (grab samples)}

Suhu penyimpanan contoh sesaat dapat dilihat pada Tabel 1 di bawah ini.

Tabel 1. Suhu penyimpanan contoh

\begin{tabular}{|c|c|}
\hline Lama penyimpanan contoh & Suhu penyimpanan \\
\hline$<2$ jam & Tidak perlu disimpan di lemari pendingin \\
\hline $2-6 \mathrm{jam}$ & $\leq 4^{\circ} \mathrm{C}$ \\
\hline $6-24 \mathrm{jam}$ & $\leq 4^{\circ} \mathrm{C}$ dan catat lama waktu penyimpanan \\
\hline$>24 \mathrm{jam}$ & Contoh tidak mewakili uji BOD \\
\hline
\end{tabular}

\section{b.Penyimpanan contoh gabungan (composite samples)}

Selama pengumpulan, penyimpanan contoh dilakukan pada suhu $\leq 4^{\circ} \mathrm{C}$. Batas periode pengumpulan contoh maksimal 24 jam dari waktu pengambilan contoh terakhir. Gunakan kriteria lama penyimpanan contoh gabungan, seperti pada pengambilan contoh sesaat (Tabel 1).

\section{c. Pengujian}

1. Menyiapkan 2 buah botol DO, menandai masing-masing botol dengan notasi $A_{1}$ dan $A_{2}$.

2. Memasukkan larutan contoh uji ke dalam masing-masing botol DO $\mathrm{A}_{1}$ dan $\mathrm{A}_{2}$ sampai meluap, kemudian menutup masing-masing botol secara hati-hati untuk menghindari terbentuknya gelembung udara.

3. Melakukan pengocokan beberapa kali, kemudian menambahkan air bebas mineral pada sekitar mulut botol DO yang telah ditutup.

4. Menyimpan botol $\mathrm{A}_{2}$ dalam lemari inkubator $20^{\circ} \mathrm{C} \pm 1^{\mathrm{O}} \mathrm{C}$ selama 5 hari.

5. Melakukan pengukuran oksigen terlarut terhadap larutan dalam botol $\mathrm{A}_{1}$, dengan alat DO meter yang terkalibrasi sesuai dengan standard Method for the Examination of Water and Wastewater 21 st Edition, 2005: Membrane electrode method (4500-O G) atau dengan metoda titrasi secara iodometri (modifikasi Azida) sesuai dengan SNI 06-6989.14-2004. Hasil pengukuran, merupakan nilai oksigen terlarut nol hari $\left(\mathrm{A}_{1}\right)$. Pengukuran oksigen terlarut pada nol hari harus dilakukan paling lama 30 menit setelah pengenceran.

6. Mengulangi pengerjaan (5) untuk botol $\mathrm{A}_{2}$ yang telah diinkubasi 5 hari \pm 6 jam. Hasil pengukuran yang diperoleh merupakan nilai oksigen terlarut 5 hari $\left(\mathrm{A}_{2}\right)$.

7. Melakukan pengerjaan (1) sampai (6) untuk penetapan blanko dengan menggunakan larutan pengencer tanpa contoh uji. Hasil pengukuran yang diperoleh merupakan nilai oksigen terlarut nol hari $\left(\mathrm{B}_{1}\right)$ dan nilai oksigen terlarut 5 hari $\left(\mathrm{B}_{2}\right)$. 
8. Melakukan pengerjaan (1) sampai (6) untuk penetapan kontrol standar dengan menggunakan larutan glukosaasam glutamat. Hasil pengukuran yang diperoleh merupakan nilai oksigen terlarut nol hari $\left(\mathrm{C}_{1}\right)$ dan nilai oksigen terlarut 5 hari $\left(\mathrm{C}_{2}\right)$.

9. Menghitung nilai BOD dengan persamaan

Keterangan:

$$
B O D_{5}=\frac{\left(A_{1}-A_{2}\right)-\left(\frac{\left(B_{1}-B_{2}\right)}{V_{B}}\right)}{P}
$$

$\mathrm{BOD}_{5}$ adalah nilai $\mathrm{BOD}_{5}$ contoh uji (mg/L).

$\mathrm{A}_{1} \quad$ adalah kadar oksigen terlarut contoh uji sebelum inkubasi (0 hari)(mg/L).

$\mathrm{A}_{2} \quad$ adalah kadar oksigen terlarut contoh uji setelah inkubasi (0 hari)(mg/L).

$\mathrm{B}_{1} \quad$ adalah kadar oksigen terlarut blanko sebelum inkubasi (0 hari)(mg/L)

$\mathrm{B}_{2} \quad$ adalah kadar oksigen terlarut blanko sebelum inkubasi (0 hari)(mg/L)

$\mathrm{V}_{\mathrm{B}} \quad$ adalah volume suspensi mikroba $(\mathrm{mL})$ dalam botol $\mathrm{DO}$ blanko

$\mathrm{V}_{\mathrm{C}} \quad$ adalah volume suspensi mikroba dalam botol contoh uji (mL)

$\mathrm{P} \quad$ adalah perbandingan volume contoh uji (V1) per volume total (V2)

Catatan : Bila contoh uji tidak ditambah bibit mikroba VB $=0$

\section{Analisa TSS}

1. Memanaskan kertas saring dalam oven pada suhu $105^{\circ} \mathrm{C}$ selama $1 \mathrm{jam}$.

2. Mendinginkan dalam desikator dan menimbang sampai berat konstan (B gram).

3. Menyaring sebanyak $10 \mathrm{ml}$ sampel kemudian memanaskan, kertas saring dan residu dalam oven pada suhu $105^{\circ} \mathrm{C}$ selama 1 jam.

4. Mendinginkan dalam desikator dan menimbang sampai berat konstan (A gram).

5. Menghitung kadar zat padat tersuspensi dengan persamaan berikut :

$$
\operatorname{TSS}(\mathrm{mg} / \mathrm{L})=\frac{(A-B) \times 1000}{C}
$$

Keterangan :

$\mathrm{A}=$ berat filter dan residu sesudah pemanasan $105^{\circ} \mathrm{C}(\mathrm{mg})$

$\mathrm{B}=$ berat filter kering sesudah pemanasan $105^{\circ} \mathrm{C}(\mathrm{mg})$

$\mathrm{C}=$ volume sampel $(\mathrm{mL})$

\section{HASIL DAN PEMBAHASAN}

\section{Hasil Penelitian}

Tabel 2. Hasil Analisa Limbah Cair Sarung Tenun Samarinda Awal dan Nilai Standar Baku Mutu

\begin{tabular}{|c|c|c|}
\hline Parameter & $\begin{array}{c}\text { Nilai Parameter Limbah } \\
\text { Sebelum diadsorbsi }\end{array}$ & Nilai Parameter Baku Mutu * \\
\hline $\mathrm{COD}(\mathrm{mg} / \mathrm{L})$ & 3810 & 100 \\
\hline $\mathrm{BOD}(\mathrm{mg} / \mathrm{L})$ & 86,0 & 50 \\
\hline $\mathrm{TSS}(\mathrm{mg} / \mathrm{L})$ & 5600 & 200 \\
\hline $\mathrm{pH}$ & 9 & $6,0-9,0$ \\
\hline
\end{tabular}

*Sesuai SK Gubernur Kalimantan Timur No.26 Tahun 2002

Tabel 3. Hasil Pengolahan Limbah Setelah Diadsorbsi Dengan Variasi Ukuran Partikel

\begin{tabular}{|c|c|c|c|c|c|c|c|}
\hline \multirow{2}{*}{ Parameter } & \multicolumn{7}{|c|}{ Variasi Ukuran (mesh) } \\
\cline { 2 - 8 } & $\mathbf{2 1 0}$ & $\mathbf{2 3 0}$ & $\mathbf{2 7 0}$ & $\mathbf{3 1 0}$ & $\mathbf{3 3 0}$ & $\mathbf{3 7 0}$ & $\mathbf{4 0 0}$ \\
\hline COD (mg/L) & 1540 & 860 & 588 & 322 & 173 & 98 & 64 \\
\hline BOD (mg/L) & 79,3 & 77,5 & 70,2 & 66,5 & 58,1 & 57,6 & 34,5 \\
\hline TSS (mg/L) & 3700 & 1400 & 568 & 478 & 351 & 243 & 168 \\
\hline $\mathrm{pH}$ & 8 & 8 & 8 & 8 & 8 & 8 & 8 \\
\hline
\end{tabular}




\section{Pembahasan}

Limbah cair industri sarung tenun Samarinda yamg digunakan sebagai sampel dalam penelitian ini berasal dari industri rumah tangga di jalan Bendahara Samarinda Seberang. Sampel yang dianalisa berasal dari limbah proses pewarnaan. Apabila data tabel kualitas air limbah sebelum diadsorpsi dibandingkan dengan nilai baku mutu limbah cair kegiatan industri sarung tenun Samarinda, maka limbah cair tersebut belum layak dibuang langsung ke perairan karena nila COD, BOD, TSS, dan $\mathrm{pH}$ melebihi ambang batas, oleh karena itu perlu perlakuan sebelum limbah tersebut dibuang ke perairan.

Dan setelah dilakukan perlakuan sampel dengan mengadsobsi menggunakan bentonit teraktivasi maka terjadi penurunan limbah cair sarung tenun di kota Samarinda yang sangat sigifikan. Maka penusunan limbah cair sarung tenun di kota Samarinda dapat dilihat dari grafik di bawah ini beserta pembahasannya.

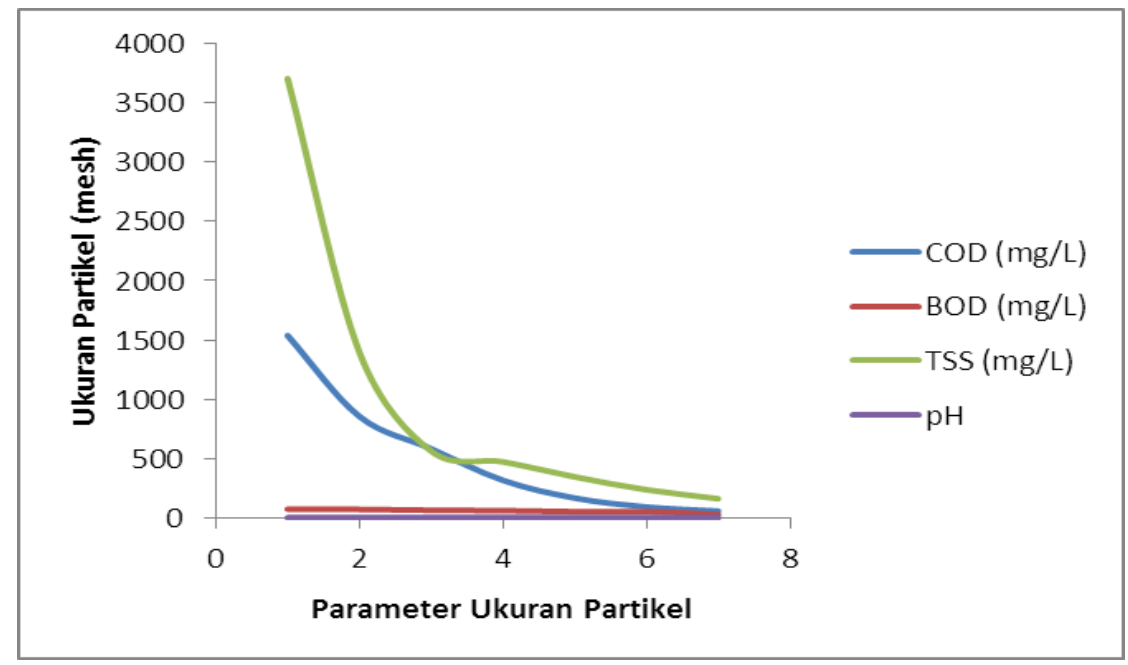

Gambar 4. Grafik Penurunan limbah cair sarung tenun Samarinda dengan bentonik teraktivasi

\section{Pengaruh Partikel Bentonit Pada Parameter BOD}

Hasil yang ditunjukkan pada grafik 1. Diatas menunjukkan bahwa nilai BOD cenderung mengalami penurunan setelah diolah. Besarnya kadar BOD sebelum pengolahan adalah $86,0 \mathrm{mg} / \mathrm{L}$ sedangkan setelah pengolahan kadar BOD mengalami penurunan sampai $34,5 \mathrm{mg} / \mathrm{L}$ pada penggunaan bentonit teraktivasi sebanyak 25 gram dan berukuran 400 mesh yang dikontakkan dalam $100 \mathrm{~mL}$ limbah cair sarung tenun Samarinda. De Congo Red mengandung gugus-gugus organik seperti Amina $\left(\mathrm{NH}_{2}\right)$ dan Sulfat $\left(\mathrm{SO}_{4}{ }^{2-}\right)$ dengan penggunaan bentonit aktif sebagai adsorben mampu menyerap zat-zat organik dalam limbah dengan cara adsorbsi pada permukaan bentonit yang sebelumnya telah diaktivasi secara kimia. Berkurangnya zat-zat organik dalam limbah akan menurunkan nilai BOD karena oksigen yang digunakan oleh mikroorganisme untuk menguraikan zat organik tersebut dalam lima hari menjadi berkurang. Namun demikian pada ukuran partikel bentonit aktif 230 mesh nilai BOD mengalami kenaikan diakibatkan semakin besar ukuran mesh maka semakin kecil pula ukuran partikel yang menyebabkan porositas bentonit menjadi kecil sehingga luas permukaan aktif bentonit semakin kecil, hal ini menyebabkan limbah tidak dapat berkontak sempurna dengan seluruh permukaan partikel bentonit, akibatnya penyerapan limbah menjadi tidak efektif sehingga nilai BOD mengalami kenaikan.

Penurunan kadar BOD dengan menggunakan bentonit aktif berukuran 400 mesh dapat dikatakan sebagai penurunan yang efektif. Berdasarkan SK Gubernur Kalimantan Timur No.26 Tahun 2002 kadar BOD yang di perkenankan sebesar $50 \mathrm{mg} / \mathrm{L}$. Hal ini berarti bahwa kadar BOD hasil pengolahan dengan adsorben bentonit aktif berukuran 400 mesh sudah memenuhi persyaratan baku mutu yang telah ditetapkan.

\section{Pengaruh Partikel Bentonit Pada Parameter COD}

Hasil pengukuran kadar COD air limbah sarung tenun Samarinda menunjukkan bahwa kadar COD mengalami penurunan dari $3810 \mathrm{mg} / \mathrm{L}$ menjadi $64 \mathrm{mg} / \mathrm{L}$ pada penggunaan bentonit teraktivasi berukuran 400 mesh. Dikarenakan semakin besar ukuran mesh maka semakin kecil ukuran partikel bentonit aktif yang menyebabkan porositas dan luas permukaan adsorben menjadi lebih besar, sehingga kemampuan adsorben bentonit dalam menjerap COD pada limbah cair menjadi lebih efektif . 
Penurunan kadar COD dengan menggunakan bentonit aktif berukuran 400 mesh dapat dikatakan sebagai penurunan yang efektif. Berdasarkan SK Gubernur Kalimantan Timur No.26 Tahun 2002 kadar COD yang di perkenankan sebesar $100 \mathrm{mg} / \mathrm{L}$. Hal ini berarti bahwa kadar COD hasil pengolahan dengan adsorben bentonit aktif berukuran 4000 mesh sudah memenuhi persyaratan baku mutu yang telah ditetapkan.

\section{Pengaruh Partikel Bentonit Pada Parameter TSS}

Hasil Pengkuran kadar TSS sebelum proses pengolahan adalah sebesar $5600 \mathrm{mg} / \mathrm{L}$. Sedangkan sesudah dilakukan adsorbsi nilai TSS dapat turun hingga $168 \mathrm{mg} / \mathrm{L}$ dengan menggunakan bentonit teraktivasi berukuran 400 mesh. Hal ini disebabkan semakin kecil ukuran bentonit maka porositas partikel semakin kecil artinya ruang kosong semakin kecil, sehingga partikel semakin rapat meyebabkan padatan tersuspensi tertahan di permukaan adsorben sehingga nilai TSS mengalami penurunan.

Penurunan kadar TSS dengan menggunakan bentonit aktif berukuran 400 mesh dapat dikatakan sebagai penurunan yang efektif. Berdasarkan SK Gubernur Kalimantan Timur No.26 Tahun 2002 kadar TSS yang di perkenankan sebesar $200 \mathrm{mg} / \mathrm{L}$. Hal ini berarti bahwa kadar TSS hasil pengolahan dengan adsorben bentonit aktif berukuran 400 mesh sudah memenuhi persyaratan baku mutu yang telah ditetapkan.

\section{Pengaruh Partikel Bentonit Pada Parameter pH}

Hasil yang didapatkan dalam pengukuran parameter $\mathrm{pH}$ yaitu limbah awal dengan $\mathrm{pH} 9$ dapat diturunkan menjadi pH 8 setelah diadsorbsi menggunakan bentonit aktif. Dikarenakan limbah cair lebih bersifat basa sehingga pada saat diadsorbsi dengan bentonit aktif gugus basa dari zat pewarna De Congo Red di dalam cair telah terdegradasi dengan bentonit aktif yang bertindak sebagai penjerap sehingga nilai $\mathrm{pH}$ dapat turun.

Pada penelitian kali ini bentonit aktif berukuran 270 mesh dapat menurunkan pH 9 menjadi pH 8 berdasarkan SK Gubernur Kalimantan Timur No.26 Tahun 2002 kadar pH yang di perkenankan sebesar pH 6 pH 9. Hal ini berarti bahwa kadar $\mathrm{pH}$ hasil pengolahan dengan adsorben bentonit aktif berukuran 400 mesh masuk dalam rentang $\mathrm{pH}$ yang ditentukan dan sudah memenuhi persyaratan baku mutu yang telah ditetapkan.

Secara umum nilai parameter COD,BOD, dan TSS cenderung semakin menurun jika ukuran bentonit aktif semakin kecil. Dikarenakan semakin kecil ukuran partikel semakin luas permukaannya, sehingga semakin banyak adsorbat yang dapat diserap.

\section{KESIMPULAN}

Berdasarkan penelitian yang telah dilakukan, maka dapat disimpulkan hal-hal berikut :

1. Parameter COD, BOD, TSS, dan $\mathrm{pH}$ pada limbah cair sarung tenun Samarinda dapat diturunkan dengan efektif menggunakan bentonit aktif partikel berukuran 400 mesh, sehingga limbah yang diolah memenuhi baku mutu yang telah ditetapkan.

2. Bentonit aktif berukuran 400 mesh dapat menurunkan kadar COD menjadi $64 \mathrm{mg} / \mathrm{L}$, BOD menjadi 34,5 $\mathrm{mg} / \mathrm{L}$, TSS menjadi $167 \mathrm{mg} / \mathrm{L}$ dan $\mathrm{pH}$ menjadi 8.

3. Parameter COD,BOD, dan TSS cenderung semakin menurun jika ukuran bentonit aktif semakin kecil. Dikarenakan semakin kecil ukuran partikel semakin luas permukaannya, sehingga semakin banyak adsorbat yang dapat diserap.

Adapun saran-saran yang dapat direkomendasikan sebagai berikut:

1. Perlu dilakukan kajian lebih lanjut mengenai pengaruh variabel lain dalam proses adsorbsi seperti temperatur, kecepatan pengadukan, dan waktu kontak adsorpsi.

2. Perlu adanya penelitian lebih lanjut untuk membuktikan apakah hasil penelitian pada skala laboratorium ini dapat diaplikasikan pada skala yang lebih besar (pilot plant).

3. Perlu adanya penelitian lebih lanjut untuk menambahkan ukuran partikel bentonit.

\section{UCAPAN TERIMA KASIH}

Peneliti mengucapkan terima kasih kepada Pusat Penelitian dan Pengabdian Pada Masyarakat Politeknik Negeri Samarinda (P2M POLNES) yang telah memberikan kesempatan untuk meneliti, dan mendapatkan pembiayaan jurnal penelitian dengan skema : prototipe penelitian dan pengembangan serta segala pihak yang telah mendukung demi kelancaran berjalannya penelitian ini. 


\section{DAFTAR PUSTAKA}

[1]. Arifin, Zaenal, dan Dedi Irawan., "Dekolorisasi Limbah Cair Industri Sarung Samarinda Menggunakan Karbon Aktif Cangkang Biji Ketapang (kack.)”, Politeknik Negeri Samarinda: Samarinda, 2010

[2]. Indrawati, Vita., "Pengaruh aktivator asam klorida terhadap daya adsorpsi bentonit pada rhodamin B", Skripsi, Jurdik Kimia, FMIPA:UNY, 2005

[3]. Keputusan Gubernur Kalimantan Timur Nomor 26 Tahun 2002 Tentang Baku mutu Limbah Cair Bagi Kegiatan Industri dan Usaha Lainnya dalam Provinsi Kalimantan Timur, 2002

[4]. McCabe, R., "Clay Chemistry”, Edisi Kedua, John Wiley \& Sons, Inc., Oxford, 1996

[5]. Mustafa, M., \& Irwan, M. "Penurunan Kadar Krom Pada Air Limbah Elektroplating dengan Menggunakan Bentonit Aktif Sebagai Adsorben”, Jurnal Riset Teknologi Industri, vol. 5, no. 10, pp. 66-75, 2016

[6]. Natalina, Putri Hulau., "Pemanfaatan Zeolit Sebagai Adsorben Untuk Menurunkan BOD dan COD Limbah Cair Tahu”, Politeknik Negeri Samarinda, Samarinda, 2010

[7]. Purnomo, A., "Sintesis, Karakterisasi Bentonit Terinterkalasi”, Program Pasca Sarjana.Universitas Gajah Mada: Yogyakarta, 2007

[8]. Ryanto, A., "Bahan Galian Industri Bentonit", Direktur Jendral Pertambangan Umum, Pusat Penelitian dan Pengembangan Mineral, Bandung, 1994

[9]. Standar Nasional Indonesia (SNI 6989.72:2009). “Air dan Ail Limbah - Bagian 72: Cara Uji Kebutuhan Oksigen Biokimia (Biochemical Oxygen Demand/BOD, 2009

[10]. Yusuf, N., "Daftar Nama Pengerajin Industri Sarung”, Kelurahan Baqa:Samarinda, 2009 http://mineralimfo.blogspot.com/20090301 